\title{
The CV as an Initiative for Sustainable Development of Small-Scale Capture Fisheries in Central Java, Indonesia
}

\author{
Siti Mahmudah*, Etty Susilowati, Yunanto, Amiek Soemarmi, Siti Malikhatun Badriyah and \\ Kornelius Benuf
}

\section{Faculty of Law, Diponegoro University, Semarang, Indonesia}

\begin{abstract}
The problem of this study is that small-scale capture fisheries business in Indonesia still faces a classic problem, namely limited sources of capital to develop the business, so a strategy is needed to overcome this problem, including working with other parties as partners in running the business. This study aims to investigate the legality of the capture fisheries business in Indonesia, and the limited partnership (Commanditaire Vennootschap/CV) as an alternative form of capture fisheries business in Indonesia. This study uses a normative juridical research method with a statutory approach and a conceptual approach, the legal data used is secondary data in the form of primary legal materials, namely the Law on Capture Fisheries and the Law on CV, and secondary legal material in the form of literature related to the research problem. The data and legal materials were collected through a literature study and analyzed descriptively and analytically. The results of the study concluded that in carrying out fishery business activities, the entrepreneurs can use CV as an alternative form of small-scale capture fisheries business that allows overcoming the problem of limited capital faced by small-scale capture fisheries entrepreneurs in Indonesia. The study concludes that with the formation of $\mathrm{CV}$, there will be two partners in small-scale capture fisheries business, namely complementary allies as the party who manages what is done by fishermen and limited allies are parties who include capital in small-scale capture fisheries businesses.
\end{abstract}

Keywords: Business development, small-scale business, small-scale capture fisheries, Central Java, Indonesia.

\section{INTRODUCTION}

Indonesia is an archipelagic country whose territorial waters are larger than its land area. The area of Indonesian waters is known to be 6.32 million $\mathrm{km}^{2}$ (six-point thirty-two million square kilometers) (Soemarmi et al., 2019), while Indonesia's land area is only 2.01 million $\mathrm{km}^{2}$ (two-point zero one square kilometer). The vast area of Indonesia's sea makes it a country with diverse and abundant marine economic potential (Retnowati, 2011; Sagita, 2017). One of the export commodities of fishery and marine products is the capture fisheries business in Indonesia. The high potential of fisheries in Indonesia makes it one of the largest fish producing countries in the world (Badriyah et al., 2019a). Capture fisheries business based on Article 1 number 2 Regulation of the Minister of Marine Affairs and Fisheries of the Republic of Indonesia Number 57/Permen-Kp/2014 concerning the Second Amendment to the Regulation of the Minister of Marine Affairs and Fisheries Number Per.30/Men/2012 concerning Capture Fisheries Business in the Fisheries Management Area of the Republic of Indonesia Indonesia, is a fishery business based on fishing activities and/or fish transportation activities. Capture fisheries business consists of several types, namely; fishing business, fish transportation business, fish

*Address correspondence to this author at the Jl. Prof. Soedarto, S.H. Tembalang, Semarang 50275, Indonesia; Tel: +62-2476918201;

Fax: +62-247691820; E-mail: sitimahmudah.undip@gmail.com catching and transportation business, and integrated fishery business as regulated in Article 3 of the Regulation of the Minister of Marine Affairs and Fisheries of the Republic of Indonesia Number 57/Permen-Kp/2014 concerning Capture Fisheries Business in the Fisheries Management Area of the Republic of Indonesia. Capture fisheries business can be owned by an individual or a fishery company, what is meant by a fishery company is a company that does business in the fisheries sector, whether it is a legal entity or not a legal entity (Article 1 point 4 ). The capture fisheries business in Indonesia is dominated by small-scale capture fisheries (Kusdiantoro et al., 2019).

Capture fisheries business is a national economic potential that plays an important role in the economy in Indonesia because it becomes a source of income for residents of coastal areas as a source of livelihood (Asiati \& Nawawi, 2017). However, in the implementation of the capture fisheries business in Indonesia, it still faces several obstacles, making it difficult to develop. It is known that to be able to fully utilize the potential of the marine economy in Indonesia, it is necessary to have a good management system (Tirtawati et al., 2020). The constraints faced by capture fisheries entrepreneurs in Indonesia which are dominated by small-scale capture fisheries businesses as well as small businesses in Indonesia are limited business capital, so they do not have a good fleet and limited fishing equipment technology (Kusdiantoro et al., 2019). This is what makes the capture fisheries 
business in Indonesia difficult to develop. The limitations of business capital experienced by capture fisheries businesses in Indonesia will be studied further in this study. The goal of this study is to explore the legality of a capture fisheries business form that is suitable to be developed in Indonesia, to solve the problem of limited capital experienced by capture fisheries businesses. The hypothesis proposed is related to on how the legality of the capture fisheries business in Indonesia with the embodiment of $\mathrm{CV}$ as an alternative form of legality, to overcome the problem of limited capital in small-scale capture fisheries in Indonesia. This study aims to investigate the legality of the capture fisheries business in Indonesia, and the limited partnership (Commanditaire Vennootschap/CV) as an alternative form of capture fisheries business in Indonesia

\section{RESEARCH METHODS}

This study uses a normative juridical research method with a conceptual approach and a statutory approach (Rianto, 2004). The legal data used in this study is secondary data consisting of primary legal materials, namely the law on capture fisheries business and the law on the CV in Indonesia, as well as secondary legal material in the form of literature related to research problems. Collecting data and legal materials through literature study, after the data and legal materials have been collected, they are then analyzed descriptively and analytically to answer research problems (Soemitro, 1990).

The approach used in this legal research is the statute approach, which is carried out by examining all laws and regulations related to the legal issue being handled, the principles, and various concepts and theories related to statutory regulations. - The legislation that is the focus of this research is the laws and regulations related to $\mathrm{CV}$, especially the Code of Commercial Law which regulates the limited partnership and laws and regulations related to the capture fisheries business. The specification of the research carried out is descriptive-analytical in nature, namely making descriptions, descriptions, or paintings systematically, factually, and accurately regarding the facts, characteristics, and relationships between the phenomena being investigated. Analytical descriptive research aims to systematically and accurately describe the facts and characteristics of a particular subject. This study, describes the shortcomings of small-scale capture fisheries business in developing capture fisheries and the advantages of profit-seeking cooperation called $\mathrm{CV}$ which can be used in the development of small-scale capture fisheries.

Data in normative legal research is called legal material, the data used in this research is qualitative, namely data that is not in the form of numbers which can be obtained from recordings, observations, interviews, or written material in the form of verbal expressions. This qualitative data is obtained from indirect sources, so it is often referred to as secondary data. The data collection method used is a literature study, which is an activity to trace, examine, and review secondary data. A literature study is carried out on legal materials which include primary legal materials, secondary legal materials, tertiary legal materials, and non-legal materials. The literature study in this research includes primary legal material consisting of laws and regulations on capture fisheries business and the Law on CV in Indonesia, as well as secondary legal materials in the form of literature related to research problems. In addition to a literature study on primary and secondary law materials, to complement and strengthen secondary data, in this study interviews were conducted with parties related to $\mathrm{CV}$ and capture fisheries business.

Data analysis used in normative legal research is qualitative analysis. The analysis emphasizes the deductive inference process to elaborate and match with hypothesis statement, and on answering research questions through formal and argumentative ways of thinking about the legality of $\mathrm{CV}$ as an alternative for small-scale captures in Indonesia.

\section{RESULTS}

The limited partnership (CV) is a form of company that is widely used in running companies in Indonesia, as can be seen in Table 1 .

Table 1: Directory of Industrial Companies in Central Java

\begin{tabular}{|c|c|c|}
\hline No. & Company Form & Number of Companies \\
\hline \hline 1. & Limited Company & 986 \\
\hline 2. & CV & 361 \\
\hline 3. & Trading unit (UD) & 346 \\
\hline 4. & Trading company (PD) & 15 \\
\hline 5. & Other & 2502 \\
\hline & Total & 4210 \\
\hline
\end{tabular}

A company in the form of a partnership is a company whose ownership is not owned by an owner 
as in a corporate company but is a collaboration of two or more people to join together voluntarily to bind themselves to enter something in the form of goods, labor or craft to look for profits and share profits. Compared with individual companies, partnership companies or business entities can accumulate greater wealth than allies, as well as in terms of corporate management. In a partnership company, it is possible to manage the company not only by one ally but also with several allies, so that the responsibility is also possible to become a shared responsibility among allies (Mahmudah, 2012).

$\mathrm{CV}$ is an alliance founded by at least one limited partner and one complimentary ally, a complementary ally that acts as a company administrator (Adhim et al., 2020). Limited allies are passive allies who are not authorized to run the company. Limited allies only must provide capital inflows to the company (Sembiring, 2004). As an alliance, in general, the legal basis for organizing $\mathrm{CV}$ activities in Indonesia is regulated in the Civil Code. According to the provisions of Article 1618 of the Civil Code, there is a mention of "regulating a partnership as an agreement between two or more people who bind themselves to include something in the partnership to share the profits obtained because of it". Whereas specifically regulated in the Code of Trade Law in chapter 3 starting from Article 19 to Article 21. Based on the principle of the "lex specialis derogat legi generalist' principle, namely the articles that regulate civil partnerships that also apply to CVs as long as Code of Trade Law does not regulate, including the provisions that regulate paid-up capital allies in civil alliances. Thus allies in CV, both complementary allies and limited partners must join or enter into the $\mathrm{CV}$. In connection with this limited partners are also called moneylenders as stipulated in Article 19 of the Commercial Law Code. Considering that limited allies are not allies of the management, it can be said that the existence of limited partners in the cooperation called CV is manifested in the form of capital payment in the form of money. Thus, the source of capital (initial) CV comes from two types of allies, as well as the risk of reduced capital is a shared risk between complementary partners and limited partners.

Based on the source, CV capital can be grouped into 2 sources, namely internal capital or income of the management and external capital or capital obtained by CV through loans from banking or non-banking institutions with certain guarantees, or without certain guarantees (Suari \& Suantra, 2015). Based on the number of owners in a company, $\mathrm{CV}$ is an alliance because the number of owners is more than one, thus $\mathrm{CV}$ is a partnership. Cooperation, in general, can be divided into two types based on its nature, namely cooperation that is economic in nature and cooperation that is non-economic (Rahutama, 2016). CV is a form of cooperation that is economical, namely cooperation that aims to seek profit. The advantage of cooperation in a $\mathrm{CV}$ is obtained by running a company.

One of the reasons $\mathrm{CV}$ is used in running the company is the limited partners who are not personally responsible for the obligations of the partnership (Marks, 2011). Limited allies are passive allies whose responsibility is limited to the input who is included in the partnership unless he commits a legal act that exceeds his authority as a passive partner who is not allowed to manage the company as regulated in Article 21 of the Code of Trade Law (Saptini, 2015). Given the characteristics or elements possessed by a CV as mentioned above, the $\mathrm{CV}$ can be a choice for individual small entrepreneurs owned by one person, who have difficulty getting venture capital in developing their business. This is because $\mathrm{CV}$ can place parties who have capital as limited partners in the ownership of $\mathrm{CV}$, so that the capital that is needed in developing a business can be fulfilled internally, without any obligations that must be fulfilled by small entrepreneurs such as paying interest and material guarantees if borrowed. Money through credit agreements with banks, which are not easily fulfilled and at the same time become an obstacle for individual small businesses to meet their capital obligations (Badriyah et al., 2019b).

\section{DISCUSSION}

In running a company, including small capture fisheries businesses, it must meet business legality which includes the legality of the activity and the legality of the form. Based on the legality of this business activity, every company that carries out business activities must meet operational requirements, while the legality of a business firm is a requirement that must be met by every form of a company regulated by the Law, which regulates the form of the company, which consists of a business entity in the form of a legal entity (with the legal entity) and not in the form of a legal entity (non-legal entity).

The legality of business activities in capture fisheries business includes; Fishery Business Permit (SIUP), Fishing Permit (SIPI), Fish Transport Ship Permit (SIKPI), as regulated in Article 11 to Article 76 
Regulation of the Minister of Marine Affairs and Fisheries of the Republic of Indonesia Number 57/Permen-Kp/2014 concerning Second Amendment to the Regulation of the Minister of Marine Affairs and Fisheries Number Per.30/Men/2012 concerning Capture Fisheries Business in the Fisheries Management Area of the Republic of Indonesia. The fulfillment of business activities in the form of obtaining these permits has encountered several obstacles, among others; distance, weather, and low education level of small-scale capture fisheries entrepreneurs.

Distance barriers, namely the extent of waters in Indonesia, on the one hand, become an opportunity for many fishing areas for fishermen, but also an obstacle for businessmen to take care of licensing. Meanwhile, the obstacles in the form of weather, due to the weather, are of great concern in issuing permits, because the management of Fisheries Business Permits (SIUP), Fishing Permits (SIPI), and Fish Transport Ship Permits (SIKPI) which require physical checks is highly dependent under weather conditions. The following obstacles are the applicant's low education level and even illiteracy, this greatly impedes the issuance of a permit because it slows down the performance of officers. After all, normal procedures use writing, but this does not make illiterate applicants not served well, although it is a bit of a hindrance still well served (Mayangsari et al., 2016).

Based on Article 1, number 2 Regulation of the Minister of Marine Affairs and Fisheries of the Republic of Indonesia Number 57/Permen-Kp/2014 concerning the Second Amendment to the Regulation of the Minister of Marine Affairs and Fisheries Number Per.30/Men/2012 concerning Capture Fisheries Business in the Fisheries Management Area of the Republic of Indonesia, determine that "Capture fisheries business is a fishery business based on fishing activities and/or fish transportation activities". Furthermore, number 3 stipulates that "Person is an individual or fishery company", while Article 1 point 4 regulates that "Fishery Company is a company that conducts business in the fisheries sector, whether it is a legal entity or not a legal entity".

According to Article 1 number 15 of Law No. 25/2009 concerning Fisheries, Corporations are organized groups of people and/or assets, both legal entities and non-legal entities. Based on the provisions of the aforementioned Articles, capture fisheries companies can be operated by legal entities or nonlegal entities. Business legality can be divided into two types, namely, the legality of business activities and the legality of business forms. Based on the legality of this business activity, every company that carries out business activities must meet operational requirements, while the legality of a business firm is a requirement that must be met by every form of a company regulated by the Law, which regulates the form of the company, which consists of business entities which in the form of a legal entity (with the legal entity) and not in the form of a legal entity (non-legal entity). Legal entities such as PT, PN, PD, and Cooperative already have adequate regulations, which are formed by taking into account social changes in Indonesia, while non-legal entities such as firm and CV (limited partnership), have yet to have specific regulations that adequate, but still refers to the Code of Trade Law and Civil Code which are no longer relevant to the country's socio-economic development (Badan Pembinaan Hukum Nasional/BPHN, 2018).

\section{CONCLUSION}

Business legality is an obligation that must be fulfilled in carrying out business activities differentiated in the legality of the activity and the legality of the form. The findings showed that regarding business development using the legality of the $\mathrm{CV}$ business from above, the CV can be used in the development of small-scale capture fisheries business in Indonesia which is still facing limited business capital. The findings further noted that even though it is known that capital for the development of small-scale fisheries business in Indonesia is very important, the application of $\mathrm{CV}$ for small business in developing small-scale capture fisheries business in Indonesia is useful as an alternative that can be a solution to classic problems faced by small-scale capture fisheries business actors in Indonesia

The results practically contribute to emphasize the role of CV as an alternative form of small-scale capture fisheries business that allows overcoming the problem of limited capital. Theoretically, CV's internal source of capital comes from more than one person, namely complementary and limited partners. In small-scale capture fisheries business, those who act as complementary allies are fishermen, while limited partners are those who include capital in small-scale capture fisheries businesses. The existence of limited partners in small-scale capture fisheries business ownership will greatly assist complementary partners in obtaining venture capital for the development of smallscale capture fisheries businesses in Indonesia. 
This research has a limitation on the discussion on the legality of small-scale capture fisheries business. Further studies are expected to explore the form of legal entities or non-legal entities as the alternative for the legality of small-scale capture fisheries business forms in Indonesia.

\section{REFERENCES}

Adhim, N., Mahmudah, S., \& Benuf, K. (2020). Juridical Study of Granting Building Utilization Rights to Limited Partnership (CV). Justitia Et Pax 36 (1). https://doi.org/10.24002/jep.v36i1.3070

Asiati, D., \& Nawawi, N. F. N. (2017). Partnerships in the Capture Fisheries Sector: Strategies for Business and Employment Sustainability. Journal of Indonesian Population, 11 (2), 103118. https://doi.org/10.14203/jki.v11i2.204

National Legal Development Agency / BPHN. (2018). Academic Paper of the Draft Law concerning Amendments to Law Number 42 of 1999 concerning Fiduciary Security. National Law Development Agency

Badriyah, S. M., Mahmudah, S., Soemarmi, A., \& Kamello, T. (2019a). Leasing Agreement on Financing SMEs in Fisheries Industry. Journal of Legal, Ethical and Regulatory Issues, 22 (3), 1-7.

Badriyah, S. M., Soemarmi, A., \& Mahmudah, S. (2019b). The Model of Business Activities Legal Responsibility in Anticipation of Environmental Pollution Impact on Sea Fish as a Food Raw Material by Small and Medium Enterprises. In 3rd International Conference on Globalization of Law and Local Wisdom (ICGLOW 2019). Atlantis Press. https://doi.org/10.2991/icglow-19.2019.7

Kusdiantoro, K., Fahrudin, A., Wisudo, S. H., \& Juanda, B. (2019). Capture fisheries in Indonesia: a portrait and challenges for its sustainability. Journal of Marine and Fisheries SocioEconomics, 14 (2), 145-162.

Mahmudah, S. (2012). Juridical Review of the Responsibilities of the Board of Directors in the Bankruptcy of Limited Liability Companies according to Law No. 40 of 2007. Legal Matters, 41 (3), 472-477.
Marks, C. P. (2011). Limited Partnership Status and the Imposition of Fiduciary Duties in Texas. Baylor L. Rev., 63, 126.

Mayangsari, A., Soemarmi, A., \& Hananto, U. D. (2016). Implementation of Duties and Authorities of the Ministry of Marine Affairs and Fisheries in the Issuance of Fisheries Business Permits in the Capture Fisheries Sector. Diponegoro Law Journal, 5 (3), 1-16.

Rahutama, R. (2016). Evaluation of the Application of Public Private Partnership in the Development and Management of the Village Market in Penyangkringan-Weleri-Kendal Regency (Review of Financial and Economic Aspects). Journal of Urban \& Regional Development, 12 (4), 446-458. https://doi.org/10.14710/pwk.v12i4.13509

Retnowati, E. (2011). Indonesian fishermen in structural poverty vortex (social, economic and legal perspectives). Perspectives, 16 (3), 149-159.

Rianto, A. (2004). Social and Legal Research Methodology. Jakarta: Granite.

Sagita, A. (2017). Optimization of fisheries courts in law enforcement of fisheries crimes in Indonesian waters. Journal of Law and Justice, 6 (2), 213-232.

Saptini, E. (2015). The Authority of Cv's Allies in Handling the Company's Operational Equipment (Doctoral dissertation, Sebelas Maret University).

Sembiring, S. (2004). Commercial Law. Citra Aditya Bakti.

Soemarmi, A., Indarti, E., Pujiyono, P., \& Diamantina, A. (2019). The concept of an archipelagic country in the effort to protect Indonesia's fisheries management areas. Legal Matters, 48(3), 241-248. https://doi.org/10.14710/mmh.48.3.2019.241-248

Soemitro, R. H. (1990). Legal and jurimetric research methodology. Jakarta: Ghalia Indonesia.

Suari, K. R. A., \& Suantra, I. N. (2015). Allied Liability to the Insolvent Commanditaire Vennootschap (CV). Kertha Semaya, Faculty of Law, Udayana University, 6 (02).

Tirtawati, S. D., Benuf, K., \& Panjaitan, B. M. (2020). Strategic Plan for the Establishment of Special Economic Zones for Small and Outermost Islands. De'jure Legal Scientific Journal: Scientific Studies of Law, 5 (1), 110-126.

\section{DOI: https://doi.org/10.6000/1929-4409.2021.10.30}

(C) 2021 Mahmudah et al.; Licensee Lifescience Global.

This is an open access article licensed under the terms of the Creative Commons Attribution Non-Commercial License (http://creativecommons.org/licenses/by-nc/3.0/) which permits unrestricted, non-commercial use, distribution and reproduction in any medium, provided the work is properly cited. 